\title{
Karın Ağrısı Şikayetiyle Acil Servise Başvuran Geriatrik Hastaların Demografik Özelliklerinin ve Prognozlarının Değerlendirilmesi
}

\author{
Evaluation of Geriatric Patients Admitted to Emergency \\ Department with a Complaint of Abdominal Pain in Terms \\ of Demographic Characteristics and Prognosis
}

Zerrin Defne Dündar ${ }^{1}$,

Mustafa Kürşat Ayrancı ${ }^{1}$,

${ }^{1}$ Necmettin Erbakan Üniversitesi, Meram Tıp Fakültesi, Acil Tıp Anabilim Dalı, Konya, Türkiye

Yazışma Adresi: Zerrin Defne Dündar, Necmettin Erbakan Üniversitesi, Meram Tıp Fakültesi, Acil Tıp Anabilim Dalı, Konya, Türkiye

e-posta: zddundar@gmail.com

\section{ORCID}

Zerrin Defne Dündar

https://orcid.org/0000-0001-6431-5800 Mustafa Kürşat Ayrancı

https://orcid.org/0000-0002-7196-0856
Geliş Tarihi/Received: 14 Eylül 2019

Kabul Tarihi/Accepted: 6 Şubat 2020

\begin{abstract}
Öz
Amaç: Bu çalışmada Acil Tıp Kliniğimize 1 yıllık süre zarfında karın ağrısı șikayeti ile başvuran 65 yaş ve üzeri hastaların demografik özelliklerinin, acil servis bakım ihtiyaçlarının ve prognozlarının değerlendirmesi amaçlanmıştır.

Hastalar ve Yöntem: Tek merkezli, retrospektif, gözlemsel çalışmaya, 15 Haziran 2015 ile 14 Haziran 2016 tarihleri arasında karın ağrısı şikayeti ile acil servise başvuran 65 yaş ve üzeri hastalar dahil edildi. Hastaların elektronik ve yazılı dosyalarından ilgili değişkenler kaydedildi. Genel hasta popülasyonu ve 65-74 yaş, $75-84$ yaş, $\geq 85$ yaş gruplarında değişkenlerin farklılıkları araştırıldı.

Bulgular: Çalışmaya toplam 1330 hasta dahil edildi. Hastaların ortalama yaşı $75,2 \pm 7,2$ idi ve 582 ' $i$ $(\% 43,8)$ erkekti. Hastaların \%58,8'i acil servisten taburcu edilirken, en sık Genel Cerrahi $(\% 14,1)$ ve Gastroenteroloji $(\% 11,4)$ kliniklerine yatırılmıştı. Yoğun bakım yatış oranı yaş ile birlikte artmaktaydı $(p<0,001 ; \% 3,3-\% 5,8-\% 11,6)$. Ortalama hastanede yatış süresi $5,9 \pm 7,1$ gündü ve hastane içi mortalite oranı $\% 3,4$ idi. $65-74$ yas grubunda hastaların $\% 50,1^{\prime} \mathrm{i}$ acil servisten konsültasyon intiyacı olmadan taburcu edilirken, $\geq 85$ yaş grubunda bu oran $\% 36,6$ 'ya düşmekteydi ve fark istatistiksel olarak anlamlıydı $(p<0,001)$. Hastaların \%34,1'inde batın ultrasonu, \%20,0'sinde batın tomografisi ve \%7,5'inde batın ultrasonu ve batın tomografisi tetkiklerinin her ikisi birden yapılmıştı.

Sonuç: 85 yaş ve üzeri karın ağrılı hastalar daha fazla tetkik gereksinimi, daha fazla konsültasyon ihtiyacı, daha fazla hastaneye yatış oranı ve daha fazla mortalite oranları ile özellikli bir hasta grubudur. Karın ağrılı yaşı hastaların acil servis yönetimi esnasında bu farklılıkların göz önünde bulundurulması hasta bakım kalitesini artırırken morbidite ve mortalite oranlarının düşmesine yardımcı olacaktır.

Anahtar Kelimeler: Karın ağrısı, geriatri, acil servis, prognoz, mortalite, batın tomografisi

\section{Abstract}

Aim: The aim of this study was to evaluate the demographic characteristics, emergency care needs and prognosis of patients aged 65 years and older who presented to our Emergency Medicine Clinic with abdominal pain for a period of one year.

Patients and Methods: In this single-center, retrospective, observational study included patients aged 65 years and older who presented to the emergency department with abdominal pain between June 15, 2015 and June 14, 2016. The related variables were recorded from the patients' electronic and written files. The general patient population and the differences of variables in the 65-74 age group, 75-84 age group and $\geq 85$ age group were investigated.

Results: A total of 1330 patients were included in the study. The mean age of the patients was $75.2 \pm$ 7.2 years and $582(43.8 \%)$ were male. While $58.8 \%$ of the patients were discharged from the emergency department, the most common hospitalization wards were General Surgery $(14.1 \%)$ and Gastroenterology $(11.4 \%)$. The ICU admission rate increased with age $(p<0.001 ; 3.3 \%-5.8 \%-11.6 \%)$. The mean length of stay in hospital was $5.9 \pm 7.1$ days and the in-hospital mortality rate was $3.4 \%$. While $50.1 \%$ of the patients in the 65-74 age group were discharged from the emergency department without consultation, this rate decreased to $36.6 \%$ in the $\geq 85$ age group and the difference was statistically significant $(p<0.001)$. Abdominal ultrasound was performed in $34.1 \%$, abdominal tomography in $20.0 \%$ and both of them in $7.5 \%$ of the patients.

Conclusion: The patients aged 85 years and older with abdominal pain are more likely to be characterized by more examination needs, more consultation needs, more hospitalization rates and higher mortality rates. Taking these differences into consideration during the management of the elderly patients with abdominal pain in emergency department will help to reduce morbidity and mortality rates while improving patient care quality.
\end{abstract}

Key words: Abdominal pain, geriatric, emergency department, prognosis, mortality, abdominal computed tomography

Atıf yapmak için: Dündar ZD, Ayrancı MK. Karın Ağrısı Şikayetiyle Acil Servise Başvuran Geriatrik Hastaların Demografik Özelliklerinin ve Prognozlarının Değerlendirilmesi. Selcuk Med 2021;37(1): 45-51

Açıklama: Yazarların hiçbiri, bu makalede bahsedilen herhangi bir ürün, aygıt veya ilaç ile ilgili maddi çıkar ilişkisine sahip değildir. Araştırma, herhangi bir dış organizasyon tarafından desteklenmedi. Yazarlar çalışmanın birincil verilerine tam erişim izni vermek ve derginin talep ettiği takdirde verileri incelemesine izin vermeyi kabul etmektedirler. 


\section{GíRiş}

Tüm dünyada acil servislere başvuran geriatrik hasta sayısı gün geçtikçe artmaktadır. Ülkemizde acil servise başvurularının yaklaşık \%15-20'sini 65 yaş ve üzeri hastalar oluşturmaktadır (1-4). Bu hasta grubunun en sık acil servis başvuru semptomlarının nefes darlığı, karın ağrısı, göğüs ağrısı ve düşme olduğu bildirilmektedir (5-7). Geriatrik acil servis hastalarının \%5-15'ini karın ağrısı nedeniyle başvuruda bulunmaktadır $(2,3,8)$.

İlerleyen yaş ile birlikte değişen fizyolojik cevaplar ve eşlik eden ek hastalıklar nedeniyle 65 yaş ve üzeri karın ağrılı hastaların acil servis yönetimi karmaşık bir süreçtir. Bu yaş grubu hastalarda, kesin tanıya ulaşmak için intiyaç duyulan tetkik, konsültasyon sayısı ile acil serviste verilmesi gereken tedaviler genç hastalara göre daha fazladır $(3,9,10)$. Yine hastaneye yatış gerektiren morbidite ve hastane içi mortalite oranları da yaş ilerledikçe artmaktadır $(8,9)$. Bu yüzden, geriatrik hastaların yönetimi konusunda acil servis hekimlerini yönlendirecek verilerin literatüre kazandırılması önemlidir.

Bu çalışmada, Acil Tıp Kliniğimize 1 yıllık süre zarfında karın ağrısı şikayeti ile başvuran 65 yaş ve üzeri hastaların demografik özelliklerinin, acil servis bakım intiyaçlarının ve prognozlarının değerlendirmesi amaçlanmıştır.

\section{HASTALAR VE YÖNTEM}

Tek merkezli, retrospektif, gözlemsel olarak dizayn edilen çalışma, Necmettin Erbakan Üniversitesi Meram Tıp Fakültesi İlaç ve Tıbbi Cihaz Dışı Araştırmalar Etik Kurulu tarafından 2016/626 sayı ile onaylandı.

Çalışmaya Necmettin Erbakan Üniversitesi Meram Tıp Fakültesi Hastanesi Acil Tıp Kliniğine 15 Haziran 2015 ile 14 Haziran 2016 tarihleri arasında karın ağrısı şikayeti ile başvuran 65 yaş ve üzeri hastalar dahil edildi. Hastaların elektronik ve yazılı dosyalarından; yaş, cinsiyet, başvuru tarihi, başvuru saati, acil serviste istenen laboratuvar ve görüntüleme tetkikleri, acil serviste istenen konsültasyonlar, hastaların yatış/taburculuk bilgileri, hastaların yatırıldığı klinik bilgisi, hastanede yatış süresi ve hastane içi mortalite bilgisi ilgili formlara kaydedildi. Genel hasta popülasyonu demografik veriler, acil serviste intiyaç duyulan tetkikler, konsültasyonlar ve mortalite verileri açısından değerlendirildi. İlerleyen yaşın çalışma değişkenlerine etkisinin incelenmesi amacıyla hastalar; 65-74 yaş grubu, 75-84 yaş grubu ve $\geq 85$ yaş grubu olmak üzere 3 gruba ayrıldı. Değişkenlerin yaş grupları arasındaki farklılıkları araştırıldı.

Çalışma verilerinin analizi SPSS 20.0 (SPSS Inc., Chicago, IL) programı kullanılarak yapıldı. Kantitatif değişkenler ortalama \pm standart sapma ve kategorik değişkenler sıklık (yüzde) olarak ifade edildi. Yaş grupları arasında karşılaştırmalar kantitatif değişkenler için tek yönlü ANOVA testi ve kategorik değişkenler için ki-kare testi kullanılarak yapıldı. $p<0,05$ değeri istatistiksel anlamlı olarak kabul edildi.

\section{BULGULAR}

15 Haziran 2015 ile 14 Haziran 2016 tarihleri arasında Acil Tıp Kliniğimize 65 yaş ve üzeri toplam 10.692 hasta başvurdu. Bu hastalardan, acil servise başvuru şikayeti karın ağrısı olan $1330(\% 12,4)$ hasta çalışmaya dahil edildi. Çalışma popülasyonunun

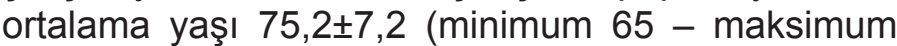
$101)$ idi. 65-74 yaş grubunda 698 (\%52,5), 75-84 yaş grubunda $468(\% 35,2)$ ve $\geq 85$ yaş grubunda $164(\% 12,3)$ hasta yer almaktaydı. Hastaların 582'i $(\% 43,8)$ erkek ve 748 'i $(\% 56,2)$ kadındı. Hastaların mevsimsel dağılımları yaklaşık birbirine benzer oranlardaydı. Hastaların \%35,7'si acil servise saat

Tablo 1. Genel hasta popülasyonu demografik verileri

\begin{tabular}{|c|c|}
\hline Değişkenler & $n=1330$ \\
\hline Yaş, yıl* & $75,2 \pm 7,2$ \\
\hline \multicolumn{2}{|l|}{ Yaş grupları } \\
\hline 65 - 74 yaş & $698(52,5)$ \\
\hline $75-84$ yaş & $468(35,2)$ \\
\hline$\geq 85$ yaş & $164(12,3)$ \\
\hline \multicolumn{2}{|l|}{ Cinsiyet } \\
\hline Erkek & $582(43,8)$ \\
\hline Kadın & $748(56,2)$ \\
\hline \multicolumn{2}{|l|}{ Acil servis başvuru mevsimi } \\
\hline Yaz (Haziran-Temmuz) & $341(25,6)$ \\
\hline Sonbahar (Eylül-Kasım) & $332(25,0)$ \\
\hline Kış (Aralık-Şubat) & $318(23,9)$ \\
\hline İlkbahar (Mart-Mayıs) & $339(25,5)$ \\
\hline \multicolumn{2}{|l|}{ Acil servis başvuru saati } \\
\hline $00.00-05.59$ & $150(11,3)$ \\
\hline $06.00-11.59$ & $293(22,0)$ \\
\hline $12.00-17.59$ & $412(31,0)$ \\
\hline $18.00-23.59$ & $475(35,7)$ \\
\hline \multicolumn{2}{|l|}{ Acil servis sonuç } \\
\hline Taburcu & $782(58,8)$ \\
\hline Servis yatış & $478(35,9)$ \\
\hline Yoğun bakım yatış & $69(5,2)$ \\
\hline Eksitus & $1(0,1)$ \\
\hline Hastanede yatış süresi, gün* & $5,9 \pm 7,1$ \\
\hline Hastane içi mortalite & $45(3,4)$ \\
\hline
\end{tabular}

* Işaretli veriler ortalama \pm standart sapma, diğer veriler $n(\%)$ olarak gösterilmiştir 
18.00 ile 23.59 arasında başvurmuştu. Ortalama hastanede yatış süresi $5,9 \pm 7,1$ gündü ve hastane içi mortalite oranı \%3,4 idi. Genel hasta popülasyonunun demografik verileri Tablo 1'de gösterilmiştir.

Acil serviste hastaların \%97,7'sine laboratuvar tetkikleri (kan, idrar, kültür, vb.), \%88,5'ine direk grafiler (akciğer grafisi, ayakta direk batın grafisi, vb.), \%34,1'ine batın ultrasonu ve \%20,0'ına batın tomografisi tetkikleri yapılmıştı. Direk grafi çekilen hastaların 587 'sinde $(\% 49,8)$ ileri görüntüleme ihtiyacı olmuştu. Hastaların 100'ünde $(\% 7,5)$ batın ultrasonu ve batın tomografisi tetkiklerinin her ikisi birden yapılmıştı.

Hastaların \%46,1'inin acil servis bakımı sırasında konsültasyon ihtiyacı olmazken, \%8,1'i 3 veya daha fazla bölüm ile konsülte edilmişti. En sık konsültasyon istenen bölümler Dahiliye (\%29,6), Genel Cerrahi $(\% 23,4)$ ve Kardiyoloji $(\% 14,7)$ idi. Hastalar acil servisten en sık Genel Cerrahi $(\% 14,1)$

Tablo 2. Genel hasta popülasyonu acil serviste yapılan işlemler ve yatış bilgileri

\begin{tabular}{|c|c|}
\hline Değişkenler & $n=1330$ \\
\hline \multicolumn{2}{|l|}{ Acil serviste yapılan tetkikler, n (\%) } \\
\hline Laboratuvar & $1299(97,7)$ \\
\hline Direk grafi & $1177(88,5)$ \\
\hline Ultrason & $453(34,1)$ \\
\hline \multicolumn{2}{|l|}{ Batın tomografisi } \\
\hline Kontrastlı (intravenöz) & $223(16,8)$ \\
\hline Kontrastsız & $43(3,2)$ \\
\hline \multicolumn{2}{|l|}{ Acil konsültasyon sayısı, n (\%) } \\
\hline Konsültasyon istenmemiş & $613(46,1)$ \\
\hline 1-2 konsültasyon & $610(45,9)$ \\
\hline 3-4 konsültasyon & $102(7,7)$ \\
\hline 5 ve üzeri konsültasyon & $5(0,4)$ \\
\hline \multicolumn{2}{|l|}{ Acil konsültasyon bölümleri, n (\%) } \\
\hline Dahiliye & $394(29,6)$ \\
\hline Genel Cerrahi & $311(23,4)$ \\
\hline Kardiyoloji & $196(14,7)$ \\
\hline Göğüs Hastalıkları & $64(4,8)$ \\
\hline Üroloji & $60(4,5)$ \\
\hline İntaniye & $55(4,1)$ \\
\hline Diğer & $49(3,7)$ \\
\hline \multicolumn{2}{|l|}{ Hastaların yattığı bölümler, n (\%) } \\
\hline Genel Cerrahi Yoğun Bakım/Servis & $188(14,1)$ \\
\hline Gastroenteroloji Servis & $151(11,4)$ \\
\hline Acil Yoğun Bakım/Gözlem & $93(7,0)$ \\
\hline Kardiyoloji Yoğun Bakım/Servis & $30(2,3)$ \\
\hline Dahiliye Yoğun Bakım & $13(1,0)$ \\
\hline Göğüs Hastalıkları Yoğun Bakım/Servis & $13(1,0)$ \\
\hline Üroloji Servis & $12(0,9)$ \\
\hline İntaniye Servis & $11(0,8)$ \\
\hline Tıbbi Onkoloji Servis & $11(0,8)$ \\
\hline Diğer & $26(2,0)$ \\
\hline
\end{tabular}

ve Gastroenteroloji $(\% 11,4)$ kliniklerine yatırılmıştı. Genel hasta popülasyonunun acil serviste yapılan işlemler ve yatış bilgileri Tablo 2'de gösterilmiştir.

Yaş grupları arasında yapılan karşılaştırmalarda, cinsiyet açısından üç grup arasında istatistiksel anlamlı fark tespit edilmedi $(p=0,398)$. Acil servis başvuru mevsimi ve başvuru saatleri açısından üç grup arasında istatistiksel anlamlı fark tespit edilmedi (sırasıyla $p=0,816$ ve $p=0,227$ ). Acil servisten taburculuk oranı, 65-74 yaş grubunda \%62,8 iken 7584 yaş grubunda $\% 56,6$ ve $\geq 85$ yaş grubunda $\% 58,8$ idi. Yoğun bakım yatış oranı yaş ile birlikte istatistiksel anlamlı olarak artmaktaydı ( $p<0,001 ; \% 3,3$ - \%5,8 - \%11,6). Hastane içi mortalite açısından gruplar arasında istatistiksel anlamlı fark tespit edilmedi $(p=0,066)$. Yaş grupları arasında demografik verilerin karşılaştırmaları Tablo 3'te gösterilmiştir.

Yaş grupları arasında yapılan karşılaştırmalarda; laboratuvar, direk grafiler, batın ultrasonu ve batın tomografisi tetkiklerinin yapılma oranları açısından gruplararasında istatistikselanlamlı fark tespitedilmedi (sırasıyla $p=0,583 ; p=0,717 ; p=0,188 ; p=0,138$ ). 6574 yaş grubunda hastaların $\% 50,1^{\prime} \mathrm{i}$ acil servisten konsültasyon ihtiyacı olmadan taburcu edilirken, $\geq 85$ yaş grubunda bu oran \%36,6'ya düşmekteydi ve fark istatistiksel olarak anlamlıydı $(p<0,001) .3$ veya daha fazla konsültasyon intiyacı olan hasta oranı 65-74 yaş grubunda $\% 6,2$ iken $\geq 85$ yaş grubunda $\% 12,2$ idi ve fark istatistiksel olarak anlamlıydı $(p<0,001)$. Yaş grupları arasında acil serviste yapılan işlemler ve yatış bilgisi karşılaştırmaları Tablo 4'te gösterilmiştir.

\section{TARTIŞMA}

Geriatrik karın ağrılı hastalar, yaş ile değişen fizyolojik cevaplar ve artan ek hastalıklar nedeniyle acil serviste özellik arz eden bir hasta grubudur. Yine acil serviste geriatrik hastaların sayısı gün geçtikçe artmaktadır. Çalışmamızda karın ağrısı nedeniyle acil servise başvuran geriatrik hastalar tüm acil servis hastalarının \%12,4'ünü oluşturmaktaydı. Literatürde geriatrik hasta başvuru oranlarının \%3 ila \%14 aralığında bildirilmektedir ve bulgularımız geriatrik hastaların acil servis hekimleri açısından önemli bir hasta yükü oluşturduğunu göstermektedir $(2,3,8)$.

Çalışmamızda hastaların ortalama yaşı 75,2 yıl olaraktespitedilmiştir. Literatürdeyeralan çalışmalarda acil servise karın ağrısı şikayetiyle başvuran yaşlı hastaların ortalama yaşı 73 ila 75 aralığında bildirilmektedir ve çalışma sonuçlarımız literatür ile uyumludur $(3,8,11)$. Çalışmamızda hastaların \%52,5'i 65-74 yaş, \%35,2'si 75-84 yaş ve \%12,3'ü 85 yaş ve 
Tablo 3. Yaş gruplarına göre demografik bilgilerin karşılaştırılması

\begin{tabular}{|c|c|c|c|c|}
\hline Değişkenler & $\begin{array}{l}65-74 \text { yaş grubu } \\
(n=698)\end{array}$ & $\begin{array}{l}75-84 \text { yaş grubu } \\
(n=468)\end{array}$ & $\begin{array}{l}\geq 85 \text { yaş grubu } \\
(n=164)\end{array}$ & p değeri \\
\hline \multicolumn{5}{|l|}{ Cinsiyet } \\
\hline Erkek & $307(44,0)$ & $211(45,1)$ & $64(39,0)$ & \multirow{2}{*}{0,398} \\
\hline Kadın & $391(56,0)$ & $257(54,9)$ & $100(61,0)$ & \\
\hline \multicolumn{5}{|c|}{ Acil servis başvuru mevsimi } \\
\hline Yaz (Haziran-Temmuz) & $178(25,5)$ & $120(25,6)$ & $43(26,2)$ & \multirow[t]{4}{*}{0,816} \\
\hline Sonbahar (Eylül-Kasım) & $165(23,6)$ & $127(27,1)$ & $40(24,4)$ & \\
\hline Kış (Aralık-Şubat) & $169(24,2)$ & $112(23,9)$ & $37(22,6)$ & \\
\hline İlkbahar (Mart-Mayıs) & $186(26,6)$ & $109(23,3)$ & $44(26,8)$ & \\
\hline \multicolumn{5}{|l|}{ Acil servis başvuru saati } \\
\hline $00.00-05.59$ & $87(12,5)$ & $44(9,4)$ & $19(11,6)$ & \multirow[t]{4}{*}{0,227} \\
\hline $06.00-11.59$ & $146(20,9)$ & $108(23,1)$ & $39(23,8)$ & \\
\hline $12.00-17.59$ & $204(29,2)$ & $149(31,8)$ & $59(36,0)$ & \\
\hline $18.00-23.59$ & $261(37,4)$ & $167(35,7)$ & $47(28,7)$ & \\
\hline \multicolumn{5}{|l|}{ Acil servis sonuç } \\
\hline Taburcu & $438(62,8)$ & $265(56,6)$ & $79(58,8)$ & \multirow[t]{3}{*}{$<0,001$} \\
\hline Servis yatış & $237(34,0)$ & $175(37,4)$ & $66(40,2)$ & \\
\hline Yoğun bakım yatış & $23(3,3)$ & $27(5,8)$ & $19(11,6)$ & \\
\hline Hastanede yatış süresi, gün* & $6,3 \pm 8,0$ & $5,3 \pm 6,6$ & $5,9 \pm 5,3$ & 0,325 \\
\hline Hastane içi mortalite & $16(2,3)$ & $22(4,7)$ & $7(4,3) \quad 0,066$ & \\
\hline
\end{tabular}

* İşaretli veriler ortalama \pm standart sapma, diğer veriler $n(\%)$ olarak gösterilmiştir

üzerindeydi. Lewis et al. (8) çalışmasında yaş grup kriterleri bizim çalışmamızdan farklı olmakla beraber, 80 yaş üzeri hasta oranı çalışmamızdan daha fazla gibi görünmektedir ki bu fark Türkiye'nin Avrupa ve Amerika ülkelerine nazaran daha genç nüfusa sahip olmasından kaynaklanmaktadır. Henden Çam et al. (11) çalışmasında ise hastaların \%52.4'ünün 6574 yaş aralığında ve geri kalan hastaların 75 yaş ve üzerinde olduğu bildirilmiştir. Çalışmamızda elde ettiğimiz yaş dağılımı Türkiye'den bildirilen sonuç ile uyumludur.

Çalışmamızda hastaların \%56,2'sinin kadın olduğu ve yaş grupları arasında kadın-erkek dağılımı açısından fark olmadığı tespit edilmiştir. Literatürde acil servise karın ağrısı ile başvuran geriatrik hastalarda kadın oranının \%51 ile \%66 arasında değiştiği ve karın ağrısının kadınlarda daha fazla görüldüğü bildirilmektedir (3,8,10-12). Çalışma sonuçlarımız mevcut literatürle uyumludur.

Acil servise karın ağrısı şikayeti ile başvuran hastalarda doğru tanıya ulaşabilmek için izlenecek algoritmalar kesin değildir. Medford-Davis et al. (13) çalışmasında karın ağrılı hastanın acil serviste doğru tanı almasını etkileyen faktörleri anamnez almadaki eksikler, yetersiz tetkik yapılması ve anormal sonucu olan testlerin yetersiz tanınması olarak bildirilmiştir. Karın ağrılı hastalarda acil serviste sık kullanılan tetkikler laboratuvar, direk grafi, batın ultrasonu ve batın bilgisayarlı tomografisidir ancak bu tetkiklerin birbirine üstünlükleri de tartışmalıdır $(12,14,15)$. Çalışmamızda, hastaların \%97,7'sine laboratuvar, $\% 88,5$ 'ine direk grafiler, \%34,1'ine batın ultrasonu ve \%20,0'sine batın bilgisayarlı tomografi tetkiki yapıldığı tespit edilmiştir. Lewis et al. (8) çalışmasında, 60 yaş ve üzeri karın ağrılı hastaların \%39'una direk grafiler, $\% 11$ 'ine batın ultrasonu ve \%38'ine batın tomografisi tetkiki istenmiştir. Pappas et al. (10) çalışmasında ise hastaların \%35'ine batın ultrasonu ve sadece $\% 5$ 'ine batın bilgisayarlı tomografi tetkiki istenmiştir. Literatürde yer alan ve çalışmamızdan elde ettiğimiz sonuçlar 65 yaş ve üzeri karın ağrılı acil servis hastalarında standart tetkik isteme algoritmalarının olmadığı ve kurumsal farklılıklar sergilendiği görüşünü desteklemektedir.

Çalışmamızda hastaların \%88,5'inde direk grafi tetkiki istenmiştir ve bu oran literatürde yer alan oranlardan oldukça yüksektir (8). Acil serviste karın ağrısı olan hastalarda direk grafi kullanımının kısıtıııkları ile ilgili pek çok çalışma sonucu literatürde yer almaktadır. Sreedharan et al. (16) çalışmalarında karın ağrısı için çekilen direk grafilerin \%12'sinde patoloji tespit edildiğini ve sadece ileus, perforasyon şüphesi gibi özel durumlarda faydalı olduğunu bildirmiştir. Zeina et al. (14) erişkin acil servis hastalarında yürüttükleri çalışmalarında, hastaların \%52'sine direk grafi çekildiğini ancak çekilen grafilerin sadece \%4,7'sinde patoloji tespit edildiğini bildirmişlerdir. Aynı çalışmada direk grafisinde 
Tablo 4. Yaş gruplarına göre acil serviste yapılan işlemler ve yatış bilgilerinin karşılaştırılması

\begin{tabular}{|c|c|c|c|c|}
\hline Değişkenler & $\begin{array}{l}\text { 65-74 yaş grubu } \\
(n=698)\end{array}$ & $\begin{array}{l}75-84 \text { yaş grubu } \\
(n=468)\end{array}$ & $\begin{array}{l}\geq 85 \text { yaş grubu } \\
(n=164)\end{array}$ & p değeri \\
\hline \multicolumn{5}{|l|}{ Acil serviste yapılan tetkikler, n (\%) } \\
\hline Laboratuvar & $680(97,4)$ & $457(97,6)$ & $162(98,8)$ & 0,583 \\
\hline Direk grafi & $613(87,8)$ & $418(89,3)$ & $146(89,0)$ & 0,717 \\
\hline Ultrason & $244(35,0)$ & $146(31,2)$ & $63(38,4)$ & 0,188 \\
\hline \multicolumn{5}{|l|}{ Batın tomografisi } \\
\hline Kontrastlı (intravenöz) & $104(14,9)$ & $86(18,4)$ & $33(20,1)$ & 0,138 \\
\hline Kontrastsız & $18(2,6)$ & $20(4,3)$ & $5(3,0)$ & \\
\hline \multicolumn{5}{|l|}{ Acil konsültasyon sayısı, n (\%) } \\
\hline Konsültasyon istenmemiş & $350(50,1)$ & $203(43,4)$ & $60(36,6)$ & 0,008 \\
\hline 1-2 konsültasyon & $305(43,7)$ & $220(47,0)$ & $85(51,8)$ & \\
\hline 3-4 konsültasyon & $41(5,9)$ & $42(9,0)$ & $19(11,6)$ & \\
\hline 5 ve üzeri konsültasyon & $2(0,3)$ & $3(0,6)$ & $3(0,6)$ & \\
\hline \multicolumn{5}{|l|}{ Acil konsültasyon bölümleri, $n$ (\%) } \\
\hline Dahiliye & $197(28,2)$ & $139(29,7)$ & $58(35,4)$ & * \\
\hline Genel Cerrahi & $148(21,2)$ & $122(26,1)$ & $41(25,0)$ & \\
\hline Kardiyoloji & $77(11,0)$ & $83(17,7)$ & $36(22,0)$ & \\
\hline Göğüs Hastalıkları & $23(3,3)$ & $29(6,2)$ & $12(7,3)$ & \\
\hline Üroloji & $27(3,9)$ & $27(5,8)$ & $6(3,7)$ & \\
\hline İntaniye & $27(3,9)$ & $19(4,1)$ & $9(5,5)$ & \\
\hline Diğer & $24(3,4)$ & $16(3,4)$ & $9(5,5)$ & \\
\hline \multicolumn{5}{|l|}{ Hastaların yattığı bölümler, n (\%) } \\
\hline Genel Cerrahi Yoğun Bakım/Servis & $94(13,5)$ & $69(14,7)$ & $25(15,2)$ & * \\
\hline Gastroenteroloji Servis & $79(11,3)$ & $52(11,1)$ & $20(12,2)$ & \\
\hline Acil Yoğun Bakım/Gözlem & $37(5,3)$ & $44(9,4)$ & $12(7,3)$ & \\
\hline Kardiyoloji Yoğun Bakım/Servis & $12(1,7)$ & $12(2,6)$ & $6(3,7)$ & \\
\hline Dahiliye Yoğun Bakım & $1(0,1)$ & $4(0,9)$ & $8(4,9)$ & \\
\hline Göğüs Hastalıkları Yoğun Bakım/Ser & $5(0,7)$ & $4(0,9)$ & $4(2,4)$ & \\
\hline Üroloji Servis & $8(1,1)$ & $3(0,6)$ & $1(0,6)$ & \\
\hline Intaniye Servis & $7(1,0)$ & $4(0,9)$ & $0(0,0)$ & \\
\hline Tıbbi Onkoloji Servis & $10(1,4)$ & $1(0,2)$ & $0(0,0)$ & \\
\hline Diğer & $8(1,1)$ & $9(1,9)$ & $9(5,4)$ & \\
\hline
\end{tabular}

*Veri dağılımı istatistiksel değerlendirmeye uygun değildir

patoloji tespit edilmeyen hastaların \%57'sinin ileri görüntüleme tetkikine ihtiyaç duyduğu bildirmiştir (14). Bizim çalışmamızda direk grafi çekilen hastaların 587 'sinde $(\% 49,8)$ ileri görüntüleme intiyacı olmuştur ve literatürde yer alan direk grafi kullanımının azaltılma intiyacı fikrini desteklemektedir.

Çalışmamızda hastaların \%34,1'ine batın ultrason tetkiki yapıldığı ve yaş grupları arasında batın ultrasonu yapılma oranları arasında fark olmadığı tespit edilmiştir. Pappas et al. (10) çalışmalarında karın ağrılı 65 yaş altı erişkinlerde \%22 olan batın ultrasonu istenme oranının 65 yaş üzeri hastalarda \%35'e çıktığını bildirmiştir. Lewis et al. (8) 60'ı, 70'li ve 80'li yaş gruplarını karşılaştırdığı karın ağrılı hasta çalışmasında, yaş grupları arasında batın ultrason intiyacı açısından anlamlı fark olmadığı bildirilmiştir. Çalışma sonuçlarımız mevcut literatür bulgularını desteklemektedir.

Karın ağrılı hastaya acil servis yaklaşımı ile ilgili literatürdeki en güncel konulardan biri batın tomografisinin hangi durumlarda kullanılması gerektiği ile ilgili tartışmalardır. Fagerström et al. (17) acil serviste yetişkin karın ağrısına yaklaşımı 26 yıllık süreçte değerlendirdiği çalışmasında, batın bilgisayarlı tomografi istenen hasta oranının \%1,6'dan \%37'ye çıktığını ve bu artış ile birlikte cerrahi tedavi oranlarının \%43'ten \%28'e gerilediğini bildirmiştir. Millet et al. (12) 75 yaş ve üzeri hastalarda yürüttükleri çalışmada, karın ağrısı ayırıcı tanısı için sistematik kontrastsız batın tomografisi çekilmesinin tanı doğruluğunu artırırken gereksiz hastaneye yatışları azalttığını bildirmiştir. Alabousi et al. (18) çalışmasında 65 yaş ve üzeri hastalarda batın tomografisi çekmek için gençlere nazaran daha düşük eşik değerlerin kullanılması gerektiğini bildirmiştir. Bizim çalışmamızda hastaların son tanıları ile ilgili bir değerlendirme yapılmamıştır, ancak hastaların \%20,0'sine batın bilgisayarlı tomografisi çekildiği ve 
batın tomografisi çekilen hastaların 178'inin (\%66,9) hastaneye yatırıldığı tespit edilmiştir. Geriatrik karın ağrılı hastaların acil servis yönetiminde batın tomografisinin önemini belirlemek için farklı dizaynlı ileri çalışmalar yapılmalıdır.

Çalışmamızda hastaların \%53,9'u için diğer bölümlerden konsültasyon istenmiş ve en sık konsültasyon istenen bölümlerin Dahiliye ve Genel Cerrahi olduğu tespit edilmiştir. Henden Çam et al. (11) çalışmasında hastaların \%75,9'u için konsültasyon ihtiyacı duyulduğu ve en sık konsültasyon istenen bölümlerin Dahiliye ve Genel Cerrahi olduğu bildirilmiştir. Çalışmamızda tespit ettiğimiz konsültasyon oranı Henden Çam et al. çalışmasından daha düşüktür ancak konsültasyon istenen bölümler ile ilgili sonuçlarımız benzerdir. Çalışmamızda konsültasyon istenme oranları yaş ile birlikte artmaktadır. Geriatrik hasta grubunun acil servis yönetiminde acil servis hekimleri sıklıkla farklı uzmanlık alanlarına intiyaç duymaktadır. Çalışma sonuçlarımız geriatrik hasta bakımında farklı bölümlerin birlikte hareket etmesinin önemini ortaya koymaktadır.

Çalışmamızda hastaların \%41,2'sinin hastaneye yatırıldığı tespit edilmiştir. Çalışmamızda artan yaş ile birlikte acil servisten taburculuk oranları azalmakta ve yoğun bakım yatış oranları artmaktaydı. Literatürde 65 yaş ve üzeri karın ağrılı hastalarda hastaneye yatış oranlarının \%40-60 olduğu ve yaş ile yatış oranlarının arttığı bildirilmektedir $(8,10,11,19)$. Çalışma sonuçlarımız acil servis hekimlerine ilerleyen yaş ile birlikte morbidite ve mortalite oranlarının arttığını göstermesi açısından değerlidir.

Çalışmamızda hastane içi mortalite oranı \%3,4 olarak tespitedilmiştir. Literatürdefarklı vakaserilerinde mortalite oranları \%5-\%15 olarak bildirilmektedir $(2,3,9,20)$. Bulgumuz mevcut literatürdeki oranlardan daha azdır ve bu fark muhtemelen hastanemizin çalıştığı bölgedeki halkın acil servisleri kullanma profilinden kaynaklanmaktadır. Çalışmamıza dahil edilen hastaların acil servise ambulans veya kendi imkanları ile mi ulaştıkları değerlendirilmemiştir. Dolayısıyla, ambulans ile acil servise gelen hastaların hastane öncesinde aldıkları tıbbi yardımın prognozu nasıl etkilediği değerlendirilememiştir.

Sonuç olarak 65 yaş ve üzeri karın ağrılı hasta sayısı acil servislerde her geçen gün artmaktadır. Ayrıca, 85 yaş ve üzeri hastalar daha fazla tetkik gereksinimi, daha fazla konsültasyon intiyacı, daha fazla hastaneye yatış oranı ve daha fazla mortalite oranları ile özellik sergileyen hastalardır. Karın ağrılı yaşı hastaların acil servis yönetimi esnasında bu farklılıkların göz önünde bulundurulması hasta bakım kalitesini artırırken morbidite ve mortalite oranlarının düşmesine yardımcı olacaktır.

Çıkar Çatışması: Çalışmada herhangi bir çıkar çatışması yoktur.

Finansal Çıkar Çatışması: Çalışmada herhangi bir finansal çıkar çatışması yoktur.

Yazışma Adresi: Zerrin Defne Dündar, Necmettin Erbakan Üniversitesi, Meram Tıp Fakültesi,Acil Tıp Anabilim Dalı 42080 Meram/Konya, Türkiye

Telefon: +90 5324682555

e-mail: zddundar@gmail.com

\section{KAYNAKLAR}

1. Ozel Akbuga B, Mamak Ekinci EB, Kayipmaz AE, et al. Analysis of the use of resources and features of presentations and the trends in geriatric patients presenting to the emergency department: 2011-2015. Turk J Geriatrics 2016;19(3):154-61.

2. Durukan $P$, Çevik $Y$, Yıldız M. Acil servise karın ağrısıyla başvuran yaşlı hastaların değerlendirilmesi. Turk J Geriatrics 2005;8(3):111-4.

3. Kostak Mert D, Durak VA, Özdemir F, et al. Acil servise karın ağrısı şikayeti ile başvuran 45-64 yaş ile 65 yaş ve üzeri hastaların karşılaştırılması ve tanılarının fizyolojik değişikliklerle ilişkisinin değerlendirilmesi. Uludağ Üniversitesi Tıp Fakültesi Dergisi 2014;43(1):7-12.

4. Gulacti U, Lok U, Celik M, et al. The ED use and non-urgent visits of elderly patients. Turk J Emerg Med 2016;16(4):1415.

5. Covino M, Petruzziello C, Onder G, et al. A 12-year retrospective analysis of differences between elderly and oldest old patients referred to the emergency department of a large tertiary hospital. Maturitas 2019;120:7-11.

6. Fayyaz J, Khursheed M, Umer Mir M, et al. Pattern of emergency department visits by elderly patients: Study from a tertiary care hospital, Karachi. BMC Geriatr 2013;13:83.

7. Liu HW, Han LN, Zhao YX, et al. Common causes of geriatric medical emergencies in China. J Geriatr Cardiol 2015;12(1):91-2.

8. Lewis LM, Banet GA, Blanda M, et al. Etiology and clinical course of abdominal pain in senior patients: $A$ prospective, multicenter study. J Gerontol A Biol Sci Med Sci 2005;60(8):1071-6.

9. Spangler R, Van Pham T, Khoujah D, et al. Abdominal emergencies in the geriatric patient. Int $\mathrm{J}$ Emerg Med 2014;7(1):43.

10. Pappas A, Toutouni H, Gourgiotis S, et al. Comparative approach to non-traumatic acute abdominal pain between elderly and non-elderly in the emergency department: A study in rural Greece. J Clin Med Res 2013;5(4):300-4.

11. Henden Çam P, Baydin A, Yürüker $S$, et al. Investigation of geriatric patients with abdominal pain admitted to emergency department. Curr Gerontol Geriatr Res 2018;2018:9109326.

12. Millet I, Sebbane M, Molinari N, et al. Systematic unenhanced CT for acute abdominal symptoms in the elderly patients improves both emergency department diagnosis and prompt 
clinical management. Eur Radiol 2017;27(2):868-77.

13. Medford-Davis L, Park E, Shlamovitz G, et al. Diagnostic errors related to acute abdominal pain in the emergency department. Emerg Med J 2016;33(4):253-9.

14. Zeina AR, Shapira-Rootman M, Mahamid A, et al. Role of plain abdominal radiographs in the evaluation of patients with non-traumatic abdominal pain. Isr Med Assoc J 2015;17(11):678-81.

15. Jang T, Chauhan V, Cundiff C, et al. Assessment of emergency physician-performed ultrasound in evaluating nonspecific abdominal pain. Am J Emerg Med 2014;32(5):457-60.

16. Sreedharan S, Fiorentino M, Sinha S. Plain abdominal radiography in acute abdominal pain-is it really necessary? Emerg Radiol 2014;21(6):597-603.
17. Fagerström $A$, Paajanen $P$, Saarelainen $H$, et al. Non-specific abdominal pain remains as the most common reason for acute abdomen: 26-year retrospective audit in one emergency unit. Scand J Gastroenterol 2017;52(10):1072-7.

18. Alabousi A, Patlas MN, Meshki M, et al. Assessing the prevalence and clinical relevance of positive abdominal and pelvic CT findings in senior patients presenting to the emergency department. Emerg Radiol 2016;23(2):111-5.

19. Gardner CS, Jaffe TA, Nelson RC. Impact of CT in elderly patients presenting to the emergency department with acute abdominal pain. Abdom Imaging 2015;40(7):2877-82.

20. Leuthauser A, Mc Vane B. Abdominal pain in the geriatric patient. Emerg Med Clin North Am 2016;34(2):363-75. 